\title{
SEÇÕES DELGADAS DE SOLOS: MÉTODO DE IMPREGNAÇÃO COM RESINA PLÁSTICA ARALDITE
}

N.de Paula ${ }^{1}$

J.K.Yamamoto ${ }^{2}$

A.A.Tognon ${ }^{1}$

É apresentado um método de impregnação de solos e rochas friáveis, para confeç̧ão de lâminas delgadas, com utilização da resina plástica Araldite. O método mostra-se satisfatóriọ, tanto pelos resultados técnicos atingidos, como por empregar resina não tóxica, altamente vantajosa sobre as convencionalmente utilizadas.

\section{CONSIDERAÇÕES GERAIS}

A confecção de seções delgadas de amostras indeformadas de solo só é possível após endurecimento destas amostas pela impregnação com material plástico.

Segundo BREWER (1964, apud TEIXEIRA MENDES et al., 1973), "O material de impregnação ideal deveria ter viscosidade tão baixa quanto possível sob as condiçöes de impregnação, uma mudança mínima de volume ao se solidificar e não ser polar. Além disso, as condições de impregnação não deverão afetar o arranjamento dos constituintes ou mudar-lhes as propriedades ópticas. Quando solidificado, o material de impregnação deverá ser duro à temperatura ambiente, incolor e isótropo em seção delgada".

As principais técnicas e os diferentes materiais usados para a impregnação em solo desenvolvidas até 1970 estão relatadas por esses autores.

\footnotetext{
IITT, São Paulo.

2 Departamento de Geologia Econômica e Geofísica Aplicada, Instituto de Geociências/USP, São Paulo.
} 
Com relação à resina Araldite, SINGH (1969) propôs um método para a impregnação de solos argilosos. $\mathrm{O}$ ar e a água dos poros da amostra eram substituídos por monômero de estireno, e, a seguir, impregnados com resina Araldite (Ciba Ltda., Duxford, Cambridge, Inglaterra) e curada à temperatura de $55^{\circ} \mathrm{C}$. Com esta técnica obtiveram-se lâminas delgadas excelentes de solos e mesmo solos montmoriloníticos puderam ser tratados com maior sucesso.

Nos últimos anos, os Laboratórios de Solos do IPT e da ESALQ vêm empregando a resina poliéster na confecção de lâminas de solo: polylite e monômero de estireno como material de impregnação. Em termos gerais, adotam a seguinte técnica:

A impregnação é feita com solução preparada com $55 \%$ de polylite, $45 \%$ de monómero de estireno e algumas gotas (6) do catalizador peróxido de metil-etil-cetona por 100 $\mathrm{ml}$ de resina. As amostras, acondicionadas em copo de vidro e secas ao ar, e posteriormente em estufa são colocadas em dissecador sob vácuo, conforme esquema apresentado na Figura 1. Sob vácuo (pressão: 17 libras/pol ${ }^{2}$ ) é iniciada a impregnação a partir da porção inferior da amostra através do gotejamento da resina. A amostra é preparada com uma ranhura lateral de modo que as gotas atinjam o fundo do copo sem provocar escorrimento sobre a amostra. Na operação de gotejamento toma-se o cuidado de não deixar que o nível da resina no copo ultrapasse a frente de molhamento verificado na amostra. Após a impregnação, que pode durar de 6 a 8 horas, as amostras são postas a secar ao ar durante 3 a 4 dias até a gelatinização da resina. A seguir, colocadas em estufa entre 40 e $50^{\circ} \mathrm{C}$ durante 5 a 6 dias para atingir a completa polimerização. Após este período 8-10 dias, a amostra está pronta a ser laminada.

Mais recentemente, o Laboratório de Solos do IPT vem desenvolvendo uma técnica de impregnação que se baseia na substituição da resina polylite pela resina plástica, conhecida comercialmente por Araldite, fabricada pela Ciba Geigy Química S.A. A araldite, misturada a um endurecedor, em temperatura ambiente, origina um produto de polimerização.

\section{MÉTODO}

A Araldite tem uma viscosidade elevada e, portanto, há necessidade de diluíla em álcool absoluto (anidro). Em termos porcentuais, a mistura deve ser preparada com 50\% em peso de Araldite (XGY-1109), 5\% de endurecedor (HY-951) e 45\% $\pm 5 \%$ de álcool anidro.

Os equipamentos e procedimentos de impregnação são os mesmos utilizados na impregnação com polylite, entretanto o conteúdo da mistura a ser preparada deve obedecer 
às seguintes quantidades: $50 \mathrm{~g}$ de resina, $5 \mathrm{~g}$ de endurecedor e $40 \mathrm{a} 50 \mathrm{~g}$ de álcool anidro.

Convém ressaltar que quantidades duas ou três vezes maiores que essas proporcionam pega rápida e o produto de reação torna-se esbranquiçado. Além disso, todo o excedente de resina do copo, após o gotejamento, deve ser entornado e a amostra impregnada deve ser levada à estufa com temperatura em torno de $40^{\circ} \mathrm{C}$ por $24 \mathrm{~h}$.

\section{CONSIDERAÇÕES FINAIS}

A metodologia desenvolvida para impregnação de solo por meio de Araldite mostra-se viável e torna-se um substituto à resina poliéster, com as seguintes vantagens:

a) baixo grau de toxicidade;

b) endurecimento e polimerização muito mais rápidos (2 dias);

c) grau de contração mais baixo que o da resina poliéster;

d) não destrói a matéria orgânica presente no solo, enquanto que o monômero de estireno é solvente de matéria orgânica.

\section{REFERÊNCIAS BIBLIOGRÁFICAS}

BREWER, R. (1964) Fabric and mineral analysis of soils. New York, John Wiley and Sons. 470p.

SINGH, R.B. (1969) A versatile method for treatment of clay soils for thinsection fabric studies. The Journal of Soil Science, 20(2):269-273.

TEIXEIRA MENDES, A.C.; FALCI, S.C.; DEMATTÊ, J.L.I. (1973) Seções delgadas de solos: método de impregnação. Anais da Escola Superior de Agricultura "Luiz de Queiroz", 30:35-48. 


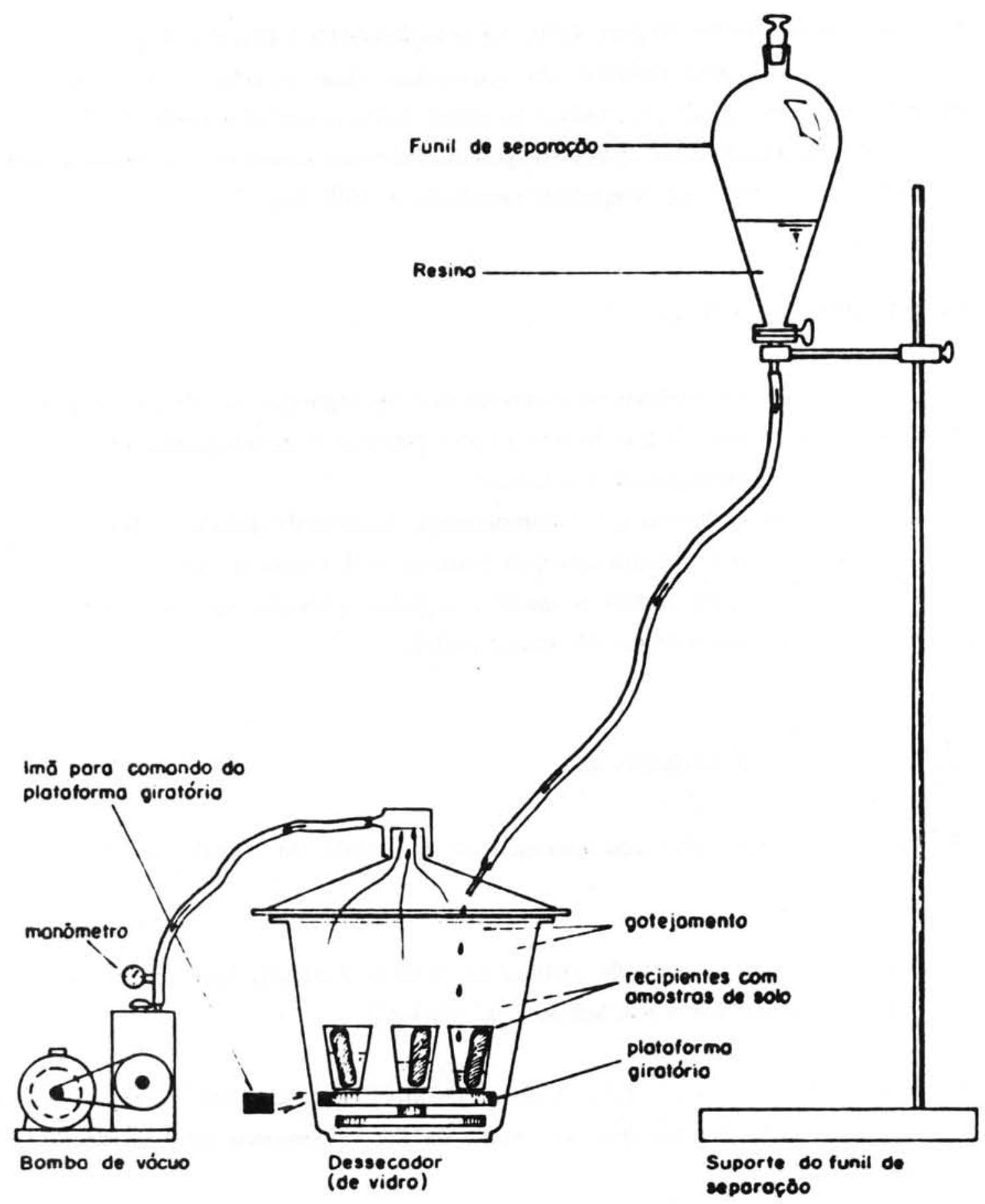

Deseonero: Luiz A. Riboiro

Figura 1 - Dispositivo para impregnação de solo sob vácuo. 